\title{
PHYSICAL ACTIVITY LEVELS AS A QUANTIFIER IN POLICE OFFICERS AND CADETS
}

\author{
ANDRZEJ SOROKA and BOGUSŁAW SAWICKI \\ University of Life Sciences in Lublin, Lublin, Poland \\ Department of Tourism and Recreation
}

\begin{abstract}
Objectives: The aim of the present study was to determine the physical activity levels of active duty police officers and police academy cadets in different life domains and intensities. These parameters were treated as potential quantifiers that could be used when assessing individuals preparing for work as future police officers. Material and Methods: The study recruited 153 active police officers and 176 cadets attending a police academy and administered a diagnostic survey, the longform version of the International Physical Activity Questionnaire, while in the statistical analysis the Student's t-test for independent groups was applied. Results: It was determined that police officers present high physical activity levels within the work domain, which are developed from initial training at a police academy and then throughout their police career. Conclusions: Such data are important in the light of the role police officers play in public safety as well as the prominence of physical activity within a particular profession and how it can be targeted and tailored to their needs.
\end{abstract}

Key words:

Physical activity, Motives, Barriers, IPAQ, Police, Cadets

\section{INTRODUCTION}

Physical activity is defined as any bodily movement where energy is expended, which can be performed either as a form of physical labor or for pleasure [1]. Many studies have concluded that low levels of physical activity, as had been initially suspected, are a major risk factor for many diseases [2]. Physical activity accounting for less than $10 \%$ of the total daily energy expenditure is considered insufficient for maintaining good health [3,4]. In addition, at least $25 \mathrm{~min}$ of physical activity per day are needed to meet the currently accepted recommendations [5].

The specific nature of the emergency services requires its employees to not only be healthy and psychologically strong, but also physically fit. Police officers, firefighters, and soldiers are all exposed to significant amounts of psychophysical stress, hence physical fitness plays a significant role during training and throughout their career. A high level of physical activity is essential not only for maintaining good health, but also to allow individuals to effectively perform their jobs [6].

In particular, the nature of police work carries with it a number of increased risks that fall outside those present in the line of duty, such as a higher prevalence of colon cancer, diabetes, cardiovascular disease, and arthritis. A higher incidence of these diseases was found among police officers when they were compared with the local population they serve in [7]. Some of the factors responsible for these health problems include mental exhaustion, poor and irregular sleep habits, and an unhealthy diet [8].

Received: November 11, 2013. Accepted: March 28, 2014.

Corresponding author: Andrzej Soroka, University of Life Sciences in Lublin, Department of Tourism and Recreation, Akademicka 13, 20-950 Lublin, Poland (e-mail: a.soroka@dydaktyka.pswbp.pl). 
However, studies point out that such negative health effects can be neutralized by increased physical activity, especially through endurance and strength training [7], confirming the earlier findings that a high level of physical activity is effective in reducing the incidence of non-communicable diseases and lowering the mortality rate of a population $[9,10]$. Therefore, of considerable importance in recruiting potential police candidates is selecting individuals who are able to meet criteria that can determine best the peak physical fitness, such as those linked to high levels of physical activity and strength abilities. Although the candidates that end up attending police academies differ in terms of their morphological features [11,12], it has been found that, due to the specificity of the physical activity that is required of them in the uniformed services, they undergo similar changes in their somatic and tissue characteristics. The purpose of this study was to determine the prevalence of physical activity of active police officers and police academy cadets by determining their overall involvement in physical activity, its intensity, as well as the domains in which it is most commonly performed, such as during work or as a form of sport or recreation. These factors were treated as potential indicators of how well police officers prepare themselves for their job. The analysis of these 2 groups, i.e. active duty police officers and cadets attending police school, was also used to determine how a career as a professional police officer influences physical activity levels over time.

\section{MATERIAL AND METHODS}

A representative sample of police officers was recruited for this study by means of stratified sampling. Five district police stations from the city of Warszawa, Poland were randomly selected, out of which 154 active-duty patrol and emergency response police officers were randomly chosen for inclusion. As for those training to become police officers, cadets participating in a half-year course at the Police Training Center in Legionowo, Poland were selected for participation. This sample was selected based on the cadets' availability during the study period and accounted for $78.5 \%$ of all attending cadets, or 176 individuals. All of the participants were males.

The morphological characteristics and age of the participants were recorded, and they revealed significant differences in the mean age of the 2 groups, which seems logical in the light of the fact that active duty police officers are individuals who already have a few years of professional experience, while police academy cadets are typically young individuals only entering their professional career. Among the group of police officers, a high standard deviation of the mean age was found, which points to a significant variation among this group. Also of interest were the relatively high mean body mass index (BMI) values of both police officers and cadets, which, based on the norms defined by Garrow [13], classified them as overweight (Table 1).

The participants' physical activity levels were assessed by the use of a diagnostic survey, the long-form version of the International Physical Activity Questionnaire (IPAQ). It was developed to monitor and measure 4 life domains in which physical activity is performed: occupational, transportation-related, household tasks-related, and recreational activity or sport [14]. The form asks respondents to report their physical activity in each domain based on its intensity (intensive, moderate, or walking), duration, and frequency. The collected data are then weighted by a metabolic equivalent (MET), resulting in a physical activity estimate that provides the total energy expenditure in METs [15]. The equivalent of 1 MET is the amount of $\mathrm{O}_{2}$ consumed at rest, or $3.5 \mathrm{ml} \mathrm{O}_{2} / \mathrm{kg}$ of the body mass per min [16]. This questionnaire is one of the most proven and widely used methods for determining physical activity levels of different social groups $[17,18]$.

The collected data were then subjected to a statistical analysis with the help of Statistica 8.1 PL software, with standard deviations and arithmetic means calculated. Variables that met the requirements for the Student's 
t-test for independent samples had their differences compared between both groups. Statistically significant differences among the means were determined at the probability of $\mathrm{p}<0.05$. When comparing the motivations as well as barriers to physical activity from the IPAQ, only the means of the answers were used for analysis.

\section{RESULTS}

The mean physical activity levels of both police officers and police academy cadets were significantly higher than what is already considered "high PA" (defined as at least $3000 \mathrm{MET}$-min/week) [19].

The police academy cadets reported higher PA than the police officers, at $p=0.028$. For both groups, the mean physical activity performed during work, which for the cadets was treated as their police officer training, was also higher than what has been adopted as "high PA". Physical activity during work accounted for $68.1 \%$ and $55.5 \%$ of the total physical activity for the police officers and cadets, respectively.

Compared to the cadets, the police officers were found to participate in more intensive physical activity, at $\mathrm{p}=0.047$, as well as to perform a larger amount of physical activity when walking, at $p=0.044$.

However, the police academy cadets performed more physical activity at moderate intensity $(p=0.037)$. As for transportation (to locations such as work on foot, by automobile, or bicycle), the cadets presented a higher level of physical activity, which accounted for $12.2 \%$ of the total physical activity, while for the police officers this was only $2 \%$.

An opposite picture was observed with physical activity related to household tasks, which for the police officers accounted for $13.3 \%$ of the total physical activity and only $2.4 \%$ in the case of the cadets, at $\mathrm{p}<0.001$.

The amount of physical activity devoted to sports as well as recreational and leisure-time activities was of considerable importance. The police officers performed significantly less $(p<0.001)$ physical activity in this domain, which accounted for only $16.6 \%$ of their total physical activity, than the cadets, for whom sports and recreational activities accounted for $29.6 \%$ of the total physical activity (Table 2, Figure 1).

Based on the participants' responses to the IPAQ, the strongest motivational factors for cadets' participation in physical activity included improving health, personal appearance and self-esteem. Among the group of active-duty police officers, improving health was the most motivating factor inducing them to participate in physical activity. In addition, the police officers noted improving personal appearance as a motivational aid, although it was less important than in the group of the police cadets, at $p=0.047$. A similar relationship between the 2 groups was observed for motivation related to improving self-esteem. Despite the high mean score of the police officers who rated this as an important facet, it was also significantly lower, at $p=0.044$, when compared to the cadets. Furthermore, despite the overall low

Table 1. Age and morphological characteristics of the police officers and police academy cadets

\begin{tabular}{lcccc}
\hline \multicolumn{1}{c}{ Analyzed parameter } & $\begin{array}{c}\text { Police officers } \\
(\mathrm{N}=154) \\
\overline{\mathrm{x}} \pm \mathrm{SD}\end{array}$ & $\begin{array}{c}\text { Cadets } \\
(\mathrm{N}=176) \\
\overline{\mathrm{x}} \pm \mathrm{SD}\end{array}$ & t-test & $\mathrm{p}$ \\
\hline Age (years) & $31.9 \pm 5.9$ & $24.3 \pm 0.7$ & 8.015 & $0.001^{*}$ \\
Body height $(\mathrm{cm})$ & $183.9 \pm 6.6$ & $179.6 \pm 8.2$ & 2.739 & $0.007^{*}$ \\
Body mass $(\mathrm{kg})$ & $85.8 \pm 8.1$ & $80.8 \pm 8.2$ & 2.878 & $0.005^{*}$ \\
Body mass index & $25.3 \pm 1.9$ & $25.0 \pm 1.3$ & 0.875 & 0.332 \\
\hline
\end{tabular}

$\overline{\mathrm{x}}$ - mean; SD - standard deviation.

* Significant at $\mathrm{p}<0.05$. 
Table 2. Physical activity levels of the active-duty police officers and police academy cadets in different life domains (MET-min/week)

\begin{tabular}{lcccc}
\hline \multicolumn{1}{c}{ Physical activity } & $\begin{array}{c}\text { Police officers } \\
(\mathrm{N}=154) \\
\overline{\mathrm{x}} \pm \mathrm{SD}\end{array}$ & $\begin{array}{c}\text { Cadets } \\
(\mathrm{N}=176) \\
\overline{\mathrm{x}} \pm \mathrm{SD}\end{array}$ & t-test & $\mathrm{p}$ \\
\hline Total physical activity & $7182.1 \pm 5695.7$ & $8318.6 \pm 3981.3$ & -2.224 & $0.028^{*}$ \\
Work - total & $4893.4 \pm 3043.8$ & $4616.7 \pm 2984.7$ & 1.043 & 0.198 \\
Work - intensive & $2106.5 \pm 1561.4$ & $1776.0 \pm 1342.6$ & 2.024 & $0.047^{*}$ \\
Work - moderate & $1238.7 \pm 976.3$ & $1628.3 \pm 1143.2$ & 2.143 & 0.037 \\
Work - walking & $1548.2 \pm 1141.7$ & $1212.4 \pm 874.3$ & 2.057 & $0.044^{*}$ \\
Transportation & $145.6 \pm 121.2$ & $1018.0 \pm 764.4$ & -3.615 & $0.001^{*}$ \\
Household tasks & $956.8 \pm 435.2$ & $200.4 \pm 187.3$ & 5.342 & $0.001^{*}$ \\
Sports and leisure-time & $1186.3 \pm 765.4$ & $2482.9 \pm 1893.2$ & -4.095 & $0.001^{*}$ \\
activities & & & & \\
\hline
\end{tabular}

Abbreviations as in Table 1.

Table 3. Motivation for participation in physical activity in the police officers and police academy cadets

\begin{tabular}{|c|c|c|c|c|}
\hline Physical activity & $\begin{array}{l}\text { Police officers } \\
(\mathrm{N}=154) \\
\overline{\mathrm{x}} \pm \mathrm{SD}\end{array}$ & $\begin{array}{c}\text { Cadets } \\
(\mathrm{N}=176) \\
\overline{\mathrm{x}} \pm \mathrm{SD}\end{array}$ & t-test & $\mathrm{p}$ \\
\hline Improve health & $4.2 \pm 0.9$ & $4.3 \pm 0.8$ & -0.720 & 0.473 \\
\hline Improve appearance & $3.8 \pm 0.9$ & $4.3 \pm 0.8$ & 2.013 & $0.047^{*}$ \\
\hline Improve self-esteem & $3.7 \pm 1.1$ & $4.2 \pm 1.0$ & -2.105 & $0.044^{*}$ \\
\hline Stand out among friends & $3.5 \pm 1.1$ & $3.7 \pm 1.2$ & -0.405 & 0.687 \\
\hline Improve physical fitness & $3.9 \pm 1.0$ & $3.8 \pm 1.0$ & 0.145 & 0.884 \\
\hline Improve social life & $3.3 \pm 1.1$ & $3.9 \pm 1.2$ & -2.142 & $0.034^{*}$ \\
\hline Self-actualization & $3.7 \pm 0.9$ & $3.9 \pm 1.1$ & -0.661 & 0.510 \\
\hline
\end{tabular}

Abbreviations as in Table 1.

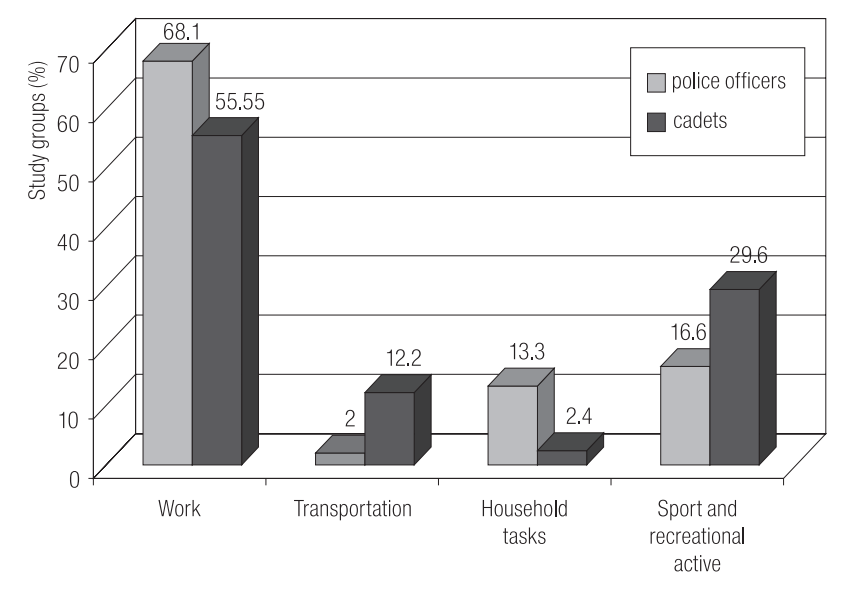

Fig. 1. Prevalence of physical activity in each of the life domains for the police officers and police academy cadets ranking of improving social life as a motivational factor by both groups, this was a significantly more important facet for the cadets than for the police officers $(p=0.034)$. The mean values for the remaining motivational factors were quite similar between the groups with no statistically significant differences (Table 3).

Based on the strength of the participants' responses, the largest barrier to participation in physical activity for both groups was the lack of knowledge on the benefits of physical activity. For the police officers, an additional barrier that was noted was the lack of overall interest in physical activity, which was a reason given significantly more often 
Table 4. Barriers to participation in physical activity among the active-duty police officers and police academy cadets

\begin{tabular}{|c|c|c|c|c|}
\hline Physical activity & $\begin{array}{l}\text { Police officers } \\
\quad(\mathrm{N}=154) \\
\overline{\mathrm{x}} \pm \mathrm{SD}\end{array}$ & $\begin{array}{c}\text { Cadets } \\
(\mathrm{N}=176) \\
\overline{\mathrm{x}} \pm \mathrm{SD}\end{array}$ & t-test & $\mathrm{p}$ \\
\hline Lack of time & $2.8 \pm 1.1$ & $2.4 \pm 1.0$ & 1.886 & 0.062 \\
\hline $\begin{array}{l}\text { Lack of access to sports } \\
\text { facilities }\end{array}$ & $2.4 \pm 1.1$ & $2.6 \pm 0.9$ & -1.248 & 0.215 \\
\hline Financial difficulties & $2.3 \pm 1.1$ & $2.6 \pm 1.0$ & -0.865 & 0.389 \\
\hline $\begin{array}{l}\text { Lack of sports/ } \\
\text { recreational skills }\end{array}$ & $2.9 \pm 1.1$ & $2.6 \pm 1.2$ & -0.405 & 0.687 \\
\hline $\begin{array}{l}\text { Lack of knowledge on } \\
\text { the benefits of physical } \\
\text { activity }\end{array}$ & $3.9 \pm 1.0$ & $3.8 \pm 1.1$ & 1.303 & 0.195 \\
\hline $\begin{array}{l}\text { Lack of interest in } \\
\text { physical activity }\end{array}$ & $3.1 \pm 0.9$ & $2.3 \pm 1.0$ & 4.054 & $0.001^{*}$ \\
\hline Fear of injury & $2.6 \pm 0.9$ & $2.1 \pm 0.8$ & 2.289 & $0.024 *$ \\
\hline $\begin{array}{l}\text { Discouragement by family } \\
\text { and friends }\end{array}$ & $2.5 \pm 1.0$ & $2.1 \pm 0.8$ & 1.651 & 0.102 \\
\hline
\end{tabular}

Abbreviations as in Table 1.

than by the cadets, at $p<0.001$. The police officers were also found to present a higher lack of sports/recreational skills and to have less available time for physical activity. The remaining mean values of the barriers towards participating in physical activity were found to be negligible between both groups.

\section{DISCUSSION}

Although it is widely recognized that regular physical activity reduces the risk of morbidity and mortality from chronic diseases [20,21], studies have found that today's work environments significantly reduce the need for engaging in physical activity, promoting a sedentary lifestyle that is frequently accompanied by a sharp increase in obesity [22].

The negative effects of a sedentary work environment apparently affect also those serving as police officers, as the relatively high BMI values found in this study for both the police officers and academy cadets categorize them as overweight, and it may seem that these 2 groups perform an insufficient amount of physical activity. However, the results of this study conclusively found that both groups presented physical activity levels well above the currently accepted norms. A similar conclusion was also reached by studies conducted on American police officers. They found that the majority of police officers are males with above-average body height and BMI values.

It has been assumed that, despite demonstrating high BMI, the profession of police officer features enough regular physical activity to allow them to properly fulfill their duties and maintain healthy levels [23]. It has been emphasized that both high levels of physical ability and physical activity are necessary in order to perform well when on duty, partly due to the frequent need to chase and detain suspects $[24,25]$.

It has been postulated that such high BMI levels are probably the result of the irregular nature of police work, compounded with poor sleep and eating habits [8], as well as the preference of police officers to exercise primarily 
through weight training. It is known that individuals engaged in strength training (such as bodybuilding) exhibit higher-than-average BMI values that could officially be indicative of obesity, even though in reality they are not [22]. Nonetheless, lower BMI has been found to positively correlate with less severe back pain and other health problems that commonly affect police officers [26].

This study found that Polish police officers exhibit high physical activity levels. It appears that officers that work in patrol and emergency response functions are forced to engage in a large amount of physical activity, while individuals training to be future police officers are apparently also well-trained due to the nature of training that takes place in police academies.

In the case of the group of cadets, this may be caused by the emphasis placed on physical training specifically related to what they may encounter in the field and on overall physical fitness, as well as the cadets' initial involvement in sports and recreational activities. This domain of physical activity in the active duty police officers was found to be emphasized less strongly.

It should be noted that when compared to the Polish population, both the police officers and cadets show impressive results. Biernat et al. [19] found that the mean physical activity of Polish women was 1200 MET-min/week and among Polish men 1500 MET-min/week. Furthermore, the results of the present study did not confirm the supposed trend of decreasing physical activity with increasing age [27-29], but this may presumably be due to the specificity of this profession in that it forces police officers even to increase if not merely maintain physical activity levels.

As had been previously mentioned, the results of the present study were found to correspond in a large part with studies on police officers and cadets in the United States. These studies also demonstrated a high physical activity level in $72 \%$ of American active duty police officers and cadets, as these were individuals who exercised regularly twice a week for at least $30 \mathrm{~min}$ at high intensity. In another study, it was found that $49 \%$ of the respondents participated in intense physical exercise at least 3 times per week [30].

This study analyzed the physical activity of active duty and future police officers, a group of incredible importance in local communities. It seems that the quality of education and training of the Polish police force in this regard is very high, as indicated by the involvement of both police officers and police academy cadets in physical activity. Such data are important in the light of the role they play in public safety as well as in underlining the prominence of physical activity within a particular profession and how it can be targeted and tailored to their needs.

\section{CONCLUSIONS}

1. There is a need to create greater awareness on the benefits of physical activity among students and the police.

2. Police officers should place stronger emphasis on healthy lifestyle, good diet and rational recreation in their free time.

3. The police training system should be preserved by promoting systematic and strict participation in sports activities among police officers.

\section{REFERENCES}

1. Pescatello LS. Exercising for heath: The merits of lifestyle physical activity. West J Med. 2001;174(2):114-8, http:// dx.doi.org/10.1136/ewjm.174.2.114.

2. Patel AV, Bernstein L, Deka A, Feigelson HS, Campbell PT, Gapstur SM, et al. Leisure time spent sitting in relation to total mortality in a prospective cohort of US adults. Am J Epidemiol. 2010;172(4):419-29, http://dx.doi.org/10.1093/aje/kwq155.

3. Varo JJ, Martinez-Gonzalez MA, de Irala-Estevez J, Kearney J, Gibney M, Martínez JA. Distribution and determinants of sedentary lifestyles in the European Union. Int J Epidemiol. 2003;32:138-46, http://dx.doi.org/10.1093/ije/dyg116. 
4. Warren TY, Barry V, Hooker SP, Sui X, Church TS, Blair SN. Sedentary behaviors increase risk of cardiovascular disease mortality in men. Med Sci Sports Exerc. 2010;42(5): 879-85, http://dx.doi.org/10.1249/MSS.0b013e3181c3aa7e.

5. Cabrera de León A, Rodríguez-Pérez MC, RodríguezBenjumeda LM, Anía-Lafuente B, Brito-Díaz B, Muros de Fuentes M, et al. Sedentary lifestyle: Physical activity duration versus percentage of energy expenditure. Rev Esp Cardiol. 2007;60(3):244-50.

6. Kalina RM, Chodała A, Tomczak A. [The extreme sports from the perspective of modern military and anti-terrorist trainings as well as effective functioning of emergency services]. In: Rakowski A, Chodała A, Kalina RM, editors. [The extreme sports as the part of preparation of the formation of anti-terrorist groups]. Warszawa: Wydawnictwo Polskiego Towarzystwa Naukowego Kultury Fizycznej; 2003. p. 7-12. Polish.

7. Bullock T. Police officer injury study. VML Insurance programs. Law Enforcement Newsletter. Health Serv Res. 2007 [cited 2013 Apr 12];23(7):821-7. Available from: http://www. vmlins.org/Newsletters/Law/injury.htm.

8. Ruiz J, Morrow E. Retiring the old centurion: Life after a career in policing - An exploratory study. Int J Pub Admin. 2005;28(13-14):1151-86, http://dx.doi.org/10.1080/ 01900690500290686.

9. Owen N, Healy GN, Matthews CE, Dunstan DW. Too much sitting: The population health science of sedentary behavior. Exerc Sport Sci Rev. 2010;38(3):105-13, http://dx.doi. org/10.1097/JES.0b013e3181e373a2.

10. Bankoski A, Harris TB, McClain JJ, Brychta RJ, Caserotti P, Chen KY, et al. Sedentary activity associated with metabolic syndrome independent of physical activity. Diabetes Care. 2011;34(2):497-503, http://dx.doi.org/10.2337/ dc10-0987.

11. Arska-Kotlińska M. [The morphological evidence of the selection of candidates for the collage officers]. In: Sokołowski M, editor. [Morpho-functional determinants and consequences of military service]. Poznań: Wydawnictwo Wyższej Szkoły Oficerskiej; 2001. p. 13-6. Polish.
12. Ziółkowska-Łajp E. The morphological conditions of the qualifying procedure for the College Officers. In: Sokołowski M, editor. The physical culture in the military in times of change. Poznań: Wydawnictwo Wyższej Szkoły Oficerskiej; 2002. p. 243-8.

13. Garrow JS. Obesity and related diseases. New York: Churchill Livingstone; 1988.

14. Miilunpalo S. Evidence and theory based promotion of health-enhancing physical activity. Pub Health Nutr. 2001;4:725-8, http://dx.doi.org/10.1079/PHN2001163.

15. Gajewska AK, Biernat E. [The use of the International Physical Activity Questionnaire (IPAQ) - for and against, that is some methodological considerations and their consequences]. In: Buśko K, Charzewska J, Kaczanowski K, editors. [Contemporary methods of studying human's activity, efficiency and physical endurance]. Warszawa: Akademia Wychowania Fizycznego; 2010. p. 20-37. Polish.

16. Piątkowska M, Pec K, Smoleń-Jasienica Z. [The participation of high school youth in various areas of physical activity]. Wychow Fiz Zdrow. 2008;6:32-41. Polish.

17. Fogelholm M, Malmberg J, Suni J, Santtila M, Kyröläinen $\mathrm{H}$, Mäntysaari $\mathrm{M}$, et al. International physical activity questionnaire: Validity against fitness. Med Sci Sports Exer. 2006;38(4):753-60, http://dx.doi.org/10.1249/01.mss. 0000194075.16960.20.

18. Welk GJ. Physical activity assessment for health related research. Champaign: Human Kinetics; 2002.

19. Biernat E, Stupnicki R, Lebiedziński B, Janczewski L. Assessment of physical by applying IPAQ questionnaire. Phys Educ Sport. 2008;52(2):83-9, http://dx.doi.org/org/10.2478/ v10030-008-0019-1.

20. Wijndaele K, Brage S, Besson H, Khaw KT, Sharp SJ, Luben $\mathrm{R}$, et al. Television viewing time independently predicts all-cause and cardiovascular. Mortal Int J Epidemiol. 2011;40(1):150-9, http://dx.doi.org/10.1093/ije/dyq105.

21. Thorp AA, Owen N, Neuhaus NM, Dunstan DM. Sedentary behaviors and subsequent health outcomes in adults: A systematic review of longitudinal studies, 1996-2011. 
Am J Prev Med. 2011;41(2):207-15, http://dx.doi.org/ 10.1016/j.amepre.2011.05.004.

22. World Health Organization. Obesity: Prevention and managing the global epidemic - Report of a WHO consultation on obesity. WHO Tech Rep Ser. 2000;894:i-xii, 1-253.

23. Smolander J, Louhevaara V, Ola P. Policemen's physical fitness in relation to the frequency of leisure-time physical exercise. Int Arch Occup Environ Health. 1984;54(4):295-302, http://dx.doi.org/10.1007/BF00378582.

24. De Loës M, Jansson B. Work-related acute injuries from mandatory fitness training in the Swedish Police Force. Int J Sports Med. 2002;23(3):212-7, http://dx.doi. org/10.1055/s-2002-23181.

25. Dishman R, Sallis J. Determinants and interventions for physical activity and exercise. In: Bouchard C, Shephard R, Stephens T, editors. Physical activity, fitness and health: International proceedings and consensus statement. Champaign: Human Kinetics; 1994. p. 214-38.
26. Nabeel I, Baker BA, McGrail MP Jr, Flottemesch TJ. Correlation between physical activity, fitness, and musculoskeletal injuries in police officers. Minn Med. 2007;90(9):40-3.

27. Brodersen NH, Steptoe A, Boniface DR, Wardle J. Trends in physical activity and sedentary behavior in adolescence: Ethnic and socioeconomic differences. Br J Sport Med. 2007;41(3):140-4, http://dx.doi.org/10.1136/bjsm.2006. 031138 .

28. Nerson MC, Neumark-Strainer D, Hannan PJ, Sirard JR, Story M. Longitudinal and secular trends in physical activity and sedentary behavior during adolescence. Pediatrics. 2006;118:1627-34, http://dx.doi.org/10.1542/peds.2006-0926.

29. Powell KE, Paluch AE, Blair SN. Physical activity for health: What kind? How much? How intense? On top of what? Ann Rev Public Health. 2011;32:349-65, http://dx.doi. org/10.1146/annurev-publhealth-031210-101151.

30. Manchikanti L. Epidemiology of low back pain. Pain Physician. 2000;(2):167-92.

This work is available in Open Access model and licensed under a Creative Commons Attribution-NonCommercial 3.0 Poland License - http://creativecommons.org/ licenses/by-nc/3.0/pl/deed.en. 